\title{
Radioterapi Eksternal terhadap Nilai Ambang Eksitabilitas Saraf Fasialis pada Radioterapi Eksternal Penderita Karsinoma Nasofaring
}

\author{
Yunaldi Altila, ${ }^{1}$ Dindy Samiadi, ${ }^{2}$ Nur Akbar Aroeman ${ }^{2}$ \\ ${ }^{1}$ Bagian Telinga Hidung Tenggorok Bedah Kepala Leher RSUD KH. Daud Arif Kuala Tungkal \\ Tanjung Jabung Barat Jambi ${ }^{2}$ Depertemen Ilmu Kesehatan Telinga Hidung Tenggorok Bedah Kepala \\ Leher Fakultas Kedokteran Universitas Padjadjaran-Rumah Sakit Dr. Hasan Sadikin Bandung
}

\begin{abstract}
Abstrak
Radioterapi eksternal (external beam radiation therapy/EBRT) merupakan pengobatan utama karsinoma nasofaring. Efek samping radioterapi eksternal yaitu neuropati saraf tepi. Radioterapi eksternal menyebabkan perubahan perbandingan antara akson dan area total serabut saraf. Tujuan penelitian ini menilai pengaruh radioterapi eksternal pada perubahan nilai ambang eksitabilitas saraf fasialis pada penderita karsinoma nasofaring. Jenis penelitian adalah studi analitik observasional dengan rancangan pre-post design. Penelitian dilakukan di Departemen Ilmu Kesehatan Telinga Hidung Tenggorok-Bedah Kepala Leher Rumah Sakit Dr. Hasan Sadikin Bandung bulan September-November 2012. Pada penelitian ini dilakukan pemeriksaan nerve excitability test (NET) praradioterapi, fraksinasi radiasi ke-15, fraksinasi ke-33, dan 4 minggu pascaradioterapi. Hasil penelitian ini dihitung dengan menggunakan uji-t berpasangan. Terdapat 26 subjek mengalami peningkatan nilai NET selama radioterapi sesuai dengan kemaknaan jumlah fraksinasinya $(p<0,001)$. Hal tersebut tidak mempunyai hubungan yang signifikan dengan jenis kelamin dan usia penderita. Simpulan, terjadi peningkatan nilai NET sesuai bertambahnya fraksinasi radiasi, namun 4 minggu pascaradioterapi mengalami penurunan nilai NET mendekati nilai praradioterapi pada penderita karsinoma nasofaring. [MKB. 2013;45(3):167-73]
\end{abstract}

Kata kunci: Karsinoma nasofaring, nerve excitability test, radioterapi eksternal

\section{Facial Nerve Excitability Values on Nasopharyngeal Carcinoma Patients who Undergo External Beam Radiotherapy}

\begin{abstract}
External radiotherapy is the main treatment for nasopharyngeal carcinoma. One of complication of the external beam radiotherapy (EBRT) is peripheral neuropathy. External radiotherapy could cause changes in ratio between axons and the total area of the nerve fibers. The purpose of this study was to assess the influence of EBRT to the changes in the value of the facial nerve excitability in nasopharyngeal carcinoma. This research was observational analytic study by pre and post design and it was performed in the months September until November, year 2012 at the Otolaryngology-Head and Neck Surgery Department of Dr. Hasan Sadikin Hospital Bandung. Nerve excitability test (NET) examination was performed just before EBRT, fractionation the 15th, fractionation the 30 th, and four weeks after EBRT. Analytical statistic calculated by using paired t-test. They were 26 subjects had significant of NET value increased during radiotherapy according to the number of fractionation $(\mathrm{p}<0.001)$. It does not have a significant relationship with gender and age of the patient. In conclusions, there is increased NET value corresponding increase in fractionation radiation, but they would be decreases approaching the original value as before EBRT on nasopharyngeal carcinoma patients. [MKB. 2013;45(3):167-73]
\end{abstract}

Key words: External beam radiotherapy, nasopharyngeal carcinoma, nerve excitability test

Korespondensi: Yunaldi Altila, dr., Bagian THT-KL RSUD KH. Daud Arif, Jl Syarif Hidayatullah No. 14 Kuala Tungkal Tanjung Jabung Barat, Jambi.mobile 085720369321 e-mail yunaldi_altila@yahoo.com 


\section{Pendahuluan}

Radioterapi eksternal (external beam radiotion therapy/EBRT) dipergunakan sebagai modalitas utama pengobatan keganasan kepala dan leher. Radioterapi bertujuan untuk mematikan sel-sel kanker tanpa merusak struktur jaringan normal di sekitarnya. Pada keadaan lain, pemberian radiasi dosis tinggi jangka waktu lama mampu merusak struktur jaringan normal yang sukar dielakkan. ${ }^{1}$ External beam radiotion therapy adalah metode radioterapi dengan sumber radiasi terletak pada suatu jarak tertentu dari tubuh pasien. Radioterapi dapat mengakibatkan efek samping pada kelenjar ludah, mukosa rongga mulut, kulit, saraf, tulang, otot, dan pembuluh darah. ${ }^{2,3}$

Kanker kepala dan leher, di luar kanker kulit atau limfoma Hodgkin/non-Hodgkin merupakan nomor enam terbanyak kasus kanker di seluruh dunia, ${ }^{4}$ sedangkan insidensi karsinoma nasofaring (KNF) di dunia termasuk sangat jarang karena kurang dari 1 per 100.000 orang. Angka kejadian KNF meningkat dua kali pada pria dibandingkan dengan wanita. ${ }^{5}$ Insidensi karsinoma nasofaring di Indonesia mencapai 4,7 per 100.000 penduduk per tahun dengan pravalensi tertinggi pada dekade 4-5 dengan perbandingan antara laki-laki dan wanita yaitu $2-3$ berbanding satu. ${ }^{6}$ Pravalensi karsinoma nasofaring (KNF) di Departemen Ilmu Kesehatan Telinga Hidung Tenggorok-Bedah Kepala Leher (THT-KL) Rumah Sakit Dr. Hasan Sadikin (RSHS) Bandung pada tahun 2005-2010 sebesar $42,1 \%$.

Lokasi tumor primer dan pola penyebarannya menjadikan operasi bukan sebagai pilihan yang utama pada penanganan KNF. ${ }^{8}$ Pilihan utama terapi KNF adalah radioterapi, khususnya KNF tidak berdiferensiasi (WHO tipe III) oleh karena bersifat radiosensitif. ${ }^{1}$ Lokasi saraf fasialis ekstratemporal berada dalam daerah pajanan radiasi yang diberikan dari arah lateral kanan dan kiri. Pengaruh radiasi pada saraf perifer dapat berupa neuropati, paralisis saraf perifer, miokimia lokal, atau neuromiotonia. ${ }^{9}$

Kelainan yang terjadi pada saraf tepi atau perifer setelah tindakan radioterapi lebih banyak dilaporkan sebagai akibat efek samping lanjut. Kerusakan serabut saraf yang lambat oleh karena radiasi diperkirakan sebagai akibat dari kerusakan langsung pada serabut saraf atau sebagai akibat tidak langsung kerusakan endotel pembuluh darah yang memperdarahinya dan terdapatnya iskemia pada jaringan sekitarnya. Fibrosis jaringan ikat dan jejas saraf sekunder juga terjadi. Pengaruh yang terjadi secara akut akibat radioterapi pada saraf tepi terutama saraf fasialis (N.VII) jarang dilaporkan.

Terdapat tiga tes yang saat ini dipergunakan untuk menilai fungsi saraf fasialis, yaitu nerve excitability test (NET), maximum stimulation test (MST), dan electroneuronography (ENoG). Dari ketiga tes tersebut, NET memiliki keunggulan yaitu biaya pemeriksaan murah, bersifat tidak invasif, dengan sensitivitas $85 \%$ dan spesifisitas $87 \%{ }^{10}$ Penelitian ini menggunakan metode NET untuk menilai efek samping akut yang terjadi pada saraf fasialis penderita KNF yang menjalani radioterapi. Cara stimulasi saraf fasialis dengan menempatkan salah satu elektroda pada kulit yang berada di atas foramen stilomastoideus dan elektroda lain ke daerah cabang saraf fasialis. Area tersebut berada $1 \mathrm{~cm}$ di bawah lobulus telinga dan terletak posterior dari ramus mandibula. Intensitas arus minimal yang efektif untuk menyebabkan kontraksi otot yang terlihat dicatat dalam satuan miliamper dan diterjemahkan sebagai minimal excitability value (MEV). ${ }^{10}$

\section{Metode}

Subjek penelitian ini dipilih secara consecutive sampling terhadap semua penderita baru KNF tipe III menurut kriteria World Health Organization (WHO). Subjek adalah penderita yang berobat ke Poliklinik THT-KL untuk dirujuk menjalani EBRT di Departemen Radioterapi Rumah Sakit Dr. Hasan Sadikin Bandung dan telah memenuhi kriteria inklusi. Kriteria inklusi penelitian ini adalah semua penderita KNF stadium I-II atau stadium III-IV yang menolak untuk menjalani kemoterapi. Subjek belum pernah mendapatkan radioterapi, kemoterapi, maupun pembedahan serta bersedia menjadi subjek penelitian dengan menandatangani surat persetujuannya ikut serta dalam penelitian. Kriteria eksklusi adalah subjek KNF yang sedang menjalani kemoterapi, tidak menyelesaikan radioterapi (drop out), mengalami kelumpuhan pada saraf fasialis, penyakit sistemik berat, penyakit sumbatan jalan napas atas, serta dalam kondisi terancam jiwanya.

Penelitian ini dilaksanakan selama September sampai November 2012 di Departemen THT-KL RSHS Bandung. Jenis penelitian ini merupakan studi analitik observasional dengan rancangan penelitian pre-post design. Data diambil dengan cara mengukur NET pada daerah cabang saraf fasialis, yaitu cabang frontalis (1), bukalis (2), dan mandibularis (3) yang dilakukan pada waktu praradioterapi, fraksinasi radiasi ke-15, ke-33, dan 4 minggu setelah selesai radioterapi. Untuk menganalisis hasil penelitian ini digunakan uji-t berpasangan, sedangkan untuk melihat hubungan faktor perancu dengan perbedaan MEV digunakan analisis varian, yaitu membandingkan perbedaan rata-rata lebih dari dua kelompok. Demikian pula, 
Tabel 1 Karakteristik Subjek Penelitian (n=26)

\begin{tabular}{|c|c|}
\hline Karakteristik & Jumlah \\
\hline \multicolumn{2}{|l|}{ Jenis kelamin } \\
\hline Laki-laki & 22 \\
\hline Wanita & 4 \\
\hline \multicolumn{2}{|l|}{ Usia (tahun) } \\
\hline$<20$ & 3 \\
\hline $21-30$ & 3 \\
\hline $31-40$ & 2 \\
\hline $41-50$ & 10 \\
\hline $51-60$ & 6 \\
\hline$>60$ & 2 \\
\hline \multicolumn{2}{|l|}{$X(\mathrm{SD}): 43,69(14,9)$} \\
\hline \multicolumn{2}{|l|}{ Rentang: $14-75$} \\
\hline \multicolumn{2}{|l|}{ Stadium ${ }^{\#}$} \\
\hline I & 1 \\
\hline II & 4 \\
\hline III & 10 \\
\hline IV & 11 \\
\hline
\end{tabular}

Keterangan: \# Stadium menurut American Joint Committee on Cancer (AJCC) 2010¹. SD: Standar deviasi

dilakukan uji-t untuk membandingkan perbedaan rata-rata kedua kelompok. Kemaknaan ditentukan berdasarkan nilai $\mathrm{p}<0,05$.

\section{Hasil}

Dari 26 subjek didapatkan karakteristik umum penderita KNF yang menjadi subjek penelitian meliputi jenis kelamin, usia, dan stadium tumor. Distribusi subjek penelitian ini berdasarkan jenis kelamin didapatkan sebanyak 22 laki-laki dan 4 wanita dengan perbandingan laki-laki:wanita adalah 5:1. Usia rata-rata subjek penelitian 43,69 tahun dengan rentang usia 14-75 tahun. Subjek yang berusia 41-50 merupakan usia terbanyak sebanyak 10 orang. Berdasarkan stadium tumor, sebagian besar subjek sudah dalam stadium IV (Tabel 1).

Pada Tabel 2 dinilai perbandingan MEV ratarata saraf fasialis kanan dengan kiri pada waktu pemeriksaan praradioterapi, juga fraksinasi radiasi ke-15, fraksinasi radiasi ke-33, dan 4 minggu pascaradioterapi, menghasilkan hubungan yang tidak bermakna $(p>0,05)$. Artinya, saraf fasialis sisi kanan dan sisi kiri mengalami efek samping radiasi yang sama.

Nilai MEV rata-rata yang diukur pada setiap waktu pemeriksaan, dibandingkan dengan nilai MEV rata-rata praradioterapi terdapat perubahan nilai yang sangat bermakna $(p<0,001)$, kecuali nilai MEV rata-rata pada fraksinasi radiasi ke-15 dibandingkan dengan nilai MEV rata-rata pada fraksinasi radiasi ke-33 terjadi perubahan nilai MEV rata-rata. Pada fraksinasi radiasi ke-33 terjadi perubahan nilai MEV rata-rata yang tidak bermakna $(p>0,05)$. Artinya setelah fraksinasi radiasi ke-15 sampai fraksinasi radiasi ke-33, reaksi efek samping akut radiasi tidak menentu, yaitu mungkin dapat menurun atau meningkat. Demikian pula nilai ambang MEV pada subjek KNF pascaradioterapi berangsur-angsur menurun mendekati nilai semula seperti pada praradioterapi (Tabel 3).

Didapatkan hubungan nilai MEV rata-rata yang tidak bermakna antara jumlah fraksinasi radiasi dan jenis kelamin subjek ( $p>0,05)$. Artinya nilai MEV tidak dipengaruhi oleh perbedaan jenis kelamin (Tabel 4). Demikian pula, MEV rata-rata dalam hubungan antara jumlah fraksinasi radiasi dengan usia subjek (Tabel 5).

Hasil pemeriksaan nerve excitability test (NET) rata-rata tiap lokasi pemeriksaan dilihat pada setiap waktu pemeriksaan, didapatkan pada daerah lokasi 1 (frontalis) puncak peningkatan nilai MEV rata-rata didapatkan pada fraksinasi radiasi ke- 33 dan kemudian akan turun mendekati 
Yunaldi A.: Radioterapi Eksternal terhadap Nilai Ambang Eksitabilitas Saraf Fasialis Radioterapi Eksternal

Tabel 2 Hasil Pengukuran MEV pada Berbagai Waktu Pemeriksaan

\begin{tabular}{|c|c|c|c|c|}
\hline \multicolumn{5}{|c|}{ Pemeriksaan } \\
\hline \multirow[t]{2}{*}{$\operatorname{MEV}(\mathbf{m A})$} & Pra & 15 Kali & 33 Kali & 4 Minggu \\
\hline & Radioterapi & Radioterapi & Radioterapi & Pascaradioterapi \\
\hline \multicolumn{5}{|l|}{ Kanan } \\
\hline $\mathrm{X}(\mathrm{SD})$ & $2,49(0,34)$ & $2,61(0,31)$ & $2,61(0,29)$ & $2,53(0,34)$ \\
\hline Median & 2,47 & 2,66 & 2,66 & 2,49 \\
\hline Rentang & $1,893,32$ & $1,92-3,31$ & $1,95-3,28$ & $1,94-3,34$ \\
\hline \multicolumn{5}{|l|}{ Kiri } \\
\hline $\mathrm{X}(\mathrm{SD})$ & $2,51(0,22)$ & $2,62(0,20)$ & $2,64(0,21)$ & $2,52(0,21)$ \\
\hline Median & 2,51 & 2,68 & 2,70 & 2,51 \\
\hline Rentang & $2,07-2,84$ & $2,23-2,95$ & $2,162,96$ & $2,14-2,88$ \\
\hline \multicolumn{5}{|c|}{$\begin{array}{l}\text { Perbandingan kanan } \\
\text { vs kiri: }\end{array}$} \\
\hline uji-t & 0,315 & 0,174 & 0,454 & 0,089 \\
\hline $\mathrm{P}$ & 0,756 & 0,864 & 0,653 & 0,930 \\
\hline \multicolumn{5}{|l|}{$\begin{array}{l}\text { Rata-rata } \\
((\text { kanan+kiri }) / 2)\end{array}$} \\
\hline $\mathrm{X}(\mathrm{SD})$ & $2,50(0,22)$ & $2,61(0,20)$ & $2,63(0,20)$ & $2,53(0,23)$ \\
\hline Median & 2,54 & 2,66 & 2,68 & 2,53 \\
\hline Rentang & $2-3,04$ & $2,662,09-2,92$ & $2,12-2,86$ & $2,04-3,07$ \\
\hline
\end{tabular}

nilai praradioterapi. Untuk lokasi 2 (bukalis) dan 3 (mandibularis) memiliki nilai MEV rata-rata yang lebih tinggi bila dibandingkan dengan lokasi 1 serta terdapat kenaikan nilai MEV rata-rata tidak terlalu tinggi. Pada pemeriksaan fraksinasi radiasi ke-15 dan ke-33 mempunyai nilai yang hampir sama, kemudian pascaradioterapi nilai MEV rata-rata mendekati nilai praradioterapi. Perubahan nilai MEV rata-rata pada tiap waktu pemeriksaan durasi radioterapi memiliki nilai yang sangat bermakna dibandingkan dengan nilai praradioterapi ( $\mathrm{p}<0,001$; Gambar).

Tabel 3 Perbandingan MEV Rata-rata dengan Waktu Pemeriksaan

\begin{tabular}{lclcc}
\hline \multicolumn{2}{c}{$\begin{array}{c}\text { Rata-rata (SD) } \\
\text { Rentang }\end{array}$} & \multicolumn{1}{c}{ Perbandingan } & $\begin{array}{c}\text { Uji-t } \\
\text { Berpasangan }\end{array}$ & p \\
\hline Prarentang & $2,50(0,22)$ & Pra vs 15 kali & 6,465 & $<0,001$ \\
\multirow{2}{*}{15 kali rentang } & $2-3,04$ & Pra vs 33 kali & 6,627 & $<0,001$ \\
\multirow{2}{*}{33 kali rentang } & $2,61(0,20)$ & Pra vs pasca & 2,754 & 0,011 \\
& $2,09-2,92$ & 15 kali vs 33 kali & 1,154 & 0,259 \\
4 minggu pascarentang & $2,63(0,20)$ & 15 kali vs pasca & 4,253 & $<0,001$ \\
& $2,12-2,86$ & 33 kali vs pasca & 4,490 & $<0,001$ \\
\end{tabular}


Yunaldi A.: Radioterapi Eksternal terhadap Nilai Ambang Eksitabilitas Saraf Fasialis Radioterapi Eksternal

Tabel 4 Perbandingan Nilai MEV Rata-rata antara Waktu Pemeriksaan dan Jenis Kelamin

\begin{tabular}{lllcc}
\hline \multicolumn{5}{c}{ Jenis Kelamin } \\
\multicolumn{1}{c}{ Waktu Pemeriksaan } & Laki-laki & Wanita & Uji-t & p \\
\hline Praradioterapi & $2,47(0,21)$ & $2,66(0,26)$ & 1,618 & 0,119 \\
15 kali radioterapi & $2,59(0,20)$ & $2,75(0,12)$ & 1,426 & 0,167 \\
33 kali radioterapi & $2,61(0,21)$ & $2,74(0,08)$ & 1,198 & 0,243 \\
4 minggu pascaradioterapi & $2,50(0,21)$ & $2,69(0,28)$ & 1,643 & 0,113 \\
\hline
\end{tabular}

Tabel 5 Korelasi antara Usia dan Nilai NET berdasarkan Waktu Pemeriksaan

\begin{tabular}{lcc}
\hline \multicolumn{1}{c}{ Korelasi } & Koefisien Korelasi (r) & $\mathbf{p}$ \\
\hline Usia dengan praradioterapi & $-0,127$ & 0,536 \\
Usia dengan 15 kali fraksi radiasi & $-0,031$ & 0,879 \\
Usia dengan 33 kali fraksi radiasi & $-0,040$ & 0,845 \\
Usia dengan pascaradioterapi & $-0,137$ & 0,503 \\
\hline
\end{tabular}

\section{Pembahasan}

Hasil penelitian ini menunjukkan KNF lebih banyak ditemukan pada laki-laki dibandingkan dengan wanita sebesar 5:1 (Tabel 1). Keadaan ini menunjukkan pada saat penelitian berlangsung penderita laki-laki yang berobat lebih banyak bila dibandingkan dengan wanita. Penderita lakilaki juga lebih banyak dilaporkan dari beberapa penelitian sebelumnya. ${ }^{6,12,13}$ Hal ini disebabkan oleh karena laki-laki lebih sering terpapar dengan zat karsinogen antara lain tembakau, alkohol, dan asap rokok.
Hasil penelitian ini juga menunjukkan bahwa KNF diderita terutama pada dekade 4-5. Hasil penelitian ini sesuai dengan hasil para peneliti lain. $., 6,12,13$ Mereka menyatakan KNF terutama diderita usia >30 tahun. Pada penelitian ini, penderita KNF yang menjadi subjek penelitian adalah penderita pada stadium I, II, III, dan IV. Stadium IV lebih banyak didapatkan daripada stadium-stadium yang lain, hal ini sesuai dengan penelitian oleh Katherine dkk. ${ }^{6}$ yang dinyatakan sebagian besar penderita datang pada stadium lanjut. Keterlambatan pengobatan pada penderita KNF karena pada stadium dini penderita tidak merasakan gejala yang khas KNF atau dapat pula

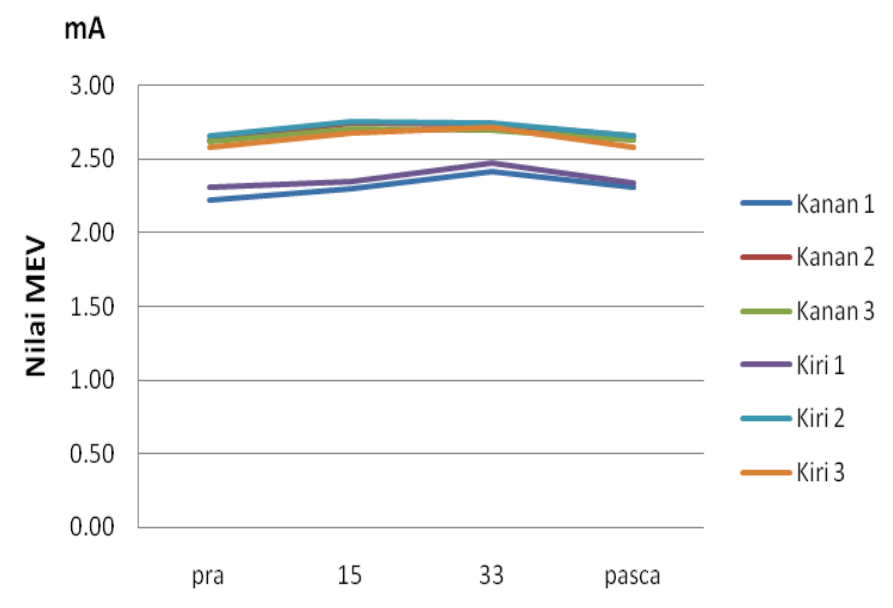

Gambar Hasil Pemeriksaan NET Rata-rata Masing-masing Waktu Pemeriksaan 
disebabkan karena letak tumor yang tersembunyi dan sulit dinilai secara klinis.

Hasil pengukuran NET yang dilakukan pada tiap cabang saraf fasialis bila dibandingkan antara sebelah kiri dan sebelah kanan memperlihatkan hasil yang tidak berbeda bermakna satu dengan yang lainnya pada setiap waktu pemeriksaan. Perbandingan pemeriksaan NET rata-rata antara sisi kanan dan kiri pada tiap waktu pemeriksaan, didapatkan hasil yang tidak bermakna. Kondisi tersebut disebabkan oleh karena pada pemberian radioterapi, dosis yang digunakan pada masingmasing sisi adalah sama, dengan total fraksinasi pemberian yang sama, sehingga masing-masing daerah pemeriksaan NET saraf fasialis mendapat pajanan yang sama.

Hasil perbandingan antara nilai MEV dan jenis kelamin pada masing-masing waktu pemeriksaan didapatkan hasil yang tidak bermakna $(\mathrm{p}>0,05)$. Hal ini berbeda dengan hasil penelitian Gates ${ }^{10}$ yang mendapatkan perbedaan NET antara lakilaki dan wanita karena body mass index (BMI) wanita sedikit lebih tinggi dibandingkan dengan pria yang berhubungan dengan ketebalan kulit. Hal ini oleh karena perbedaan karakterisitik jenis kelamin subjek pada penelitian Gates. Di sisi lain, kesamaan dengan penelitian Gates bahwa perbedaan usia tidak memengaruhi kenaikan nilai NET rata-rata karena penderita umumnya pada dekade yang sama yaitu usia dekade. ${ }^{4-5}$

Peningkatan nilai MEV saat dilakukan radiasi terjadi akibat perubahan akut pada kulit berupa eritema, juga edema dan kulit menjadi bersisik. ${ }^{14}$ Perubahan yang lain yaitu permeabilitas vaskular dan kerusakan neurolema. Efek samping pada serabut saraf diawali dengan gangguan elektrik pada membran sel, permeabilitas pembuluh darah yang memperdarahinya, dan juga pembengkakan akson akibat radiasi. ${ }^{9,15}$ Pada 4 minggu radiasi didapatkan nilai NET rata-rata yang kembali mendekati nilai NET rata-rata yang sama pada saat praradioterapi. Keadaan ini disebabkan oleh karena sudah dimulai proses reparasi (repair) sel kulit, sel penunjang di sekitar serabut saraf. Sementara itu, telah diketahui bahwa serabut saraf mempunya batas ambang sensitivitas tinggi tidak mengakibatkan kerusakan permanen akibat tindakan radioretapi.

Terdapat perbedaan nilai MEV rata-rata tiap lokasi pemeriksaan disebabkan karena kulit di bagian frontalis lebih tipis dibandingkan dengan di daerah lain serta posisi saraf fasialis terhadap kelenjar parotis pada tiap lokasi agak berbeda. Cabang frontalis berada lebih superfisial dan sebagian kecil yang berjalan di bawah kelenjar parotis dibandingkan dengan cabang bukalis dan mandibula.

Sebagai simpulan, metode NET dapat menilai peningkatan ambang nilai minimal excitability value (MEV) pada saraf fasialis terutama di daerah frontalis yang lebih cepat terjadi peningkatan nilai ambang eksitabilitas akibat efek samping akut tindakan EBRT. Meskipun demikian, efek samping yang bersifat reversibel akan mendekati keadaan semula setelah 4 minggu radioterapi.

\section{Daftar Pustaka}

1. Chan AT, Teo PM, Johnson PJ. Nasopharyngeal carcinoma. Ann Oncol. 2002;13(7):1007-15.

2. Hussey D, Wen B. Principles of radiation oncology. Dalam: Bailey B, Johnson J, Newlands S, penyunting. Head and neck surgery-otolaryngology. Edisi ke-4. Philadelphia: Lipincott Williams \& Wilkins; 2006. hlm. 1199-210.

3. Ang K, Milas L, Shiu A. General principles of radiation therapy for cancer of the head and neck. Dalam: Meyer, penyunting. Cancer of the head and neck. Edisi ke-5. Philadelphia: Saunders; 2003. hlm. 717-45.

4. Argiris A, Eng C. Epidemiology, staging, and screening of head and neck cancer. Cancer Treat Res. 2003;114:15-60.

5. Kumar S. Epidemiological and etiological factors associated with nasopharyngeal carcinoma. ICMR Bull. 2003;33(9):5-11.

6. Katherine M, Samiadi D, Purwanto B. Korelasi antara kadar imunoglobulin A VCA virus Epstein Barr serum dengan derajat tumor primer karsinoma nasofaring WHO tipe III sebelum dan sesudah radioterapi [tesis]. Bandung: Universitas Padjadjaran; 2010.

7. Laporan tahunan kunjungan penderita di Departemen THT-KL FK Unpad/RS Dr. Hasan Sadikin Bandung tahun 2005-2010. Bandung: Departemen Telinga Hidung Tenggorok-Bedah Kepala Leher FK Unpad/ RS Dr. Hasan Sadikin; 2011.

8. Faivre S, Janot F, Armand JP. Optimal management of nasopharyngeal carcinoma. Curr Opin Oncol. 2004;16(3):231-5.

9. Vasić L. Radiation-induced peripheral neuropathies: etiopathogenesis, risk factors, differential diagnostics, symptoms and treatment. Arch Oncol. 2007;15(3-4):81-4.

10. Gates GA. Nerve excitability testing: technical pitfalls and threshold norms using absolute values. Laryngoscope. 1993;103(4 Pt 1):379-85.

11. Edge S, Byrd D, Compton C. AJCC: cancer staging manual. Edisi ke-7. New York: Springer; 2010. 
12. Cannon T, Zanation A, Lai V, Weissler MC. Nasopharyngeal carcinoma in young patients: a systematic review of racial demographics. Laryngoscope. 2006;116(6):1021-6.

13. Sofyan F, Samiadi D, Soeseno B. Pengaruh radioterapi eksternal terhadap ketebalan tunika intima dan media arteri karotis komunis pada penderita karsinoma nasofaring [tesis]. Bandung: Universitas Padjadjaran; 2010.

14. López E, Guerrero R, Núñez MI, del Moral R, Villalobos M, Martínez-Galán
$\mathrm{J}$, dkk. Early and late skin reactions to radiotherapy for breast cancer and their correlation with radiation-induced DNA damage in lymphocytes. Breast Cancer Res. 2005;7(5):R690-8.

15. Friedrich RE, Lasson K, Laas R, Hagel C, Bartel-Friedrich S. Morphometrics of the facial nerve following fractionated external irradiation: an experimental study in rats. Anticancer Res. 2010;30(5):1625-32. 